\title{
OD SURGE DO PAŃSTWA ISLAMSKIEGO. PRZYCZYNY I UWARUNKOWANIA DESTABILIZACJI IRAKU PO 2011 ROKU
}

Inwazja na Irak była najważniejszym oraz najbardziej kontrowersyjnym projektem politycznym, podjętym w okresie rządów administracji prezydenta Georga W. Busha. Konsekwencje decyzji o rozpoczęciu działań zbrojnych wobec tego państwa, odczuwane są nadal, zarówno przez Stany Zjednoczone, jak i przez Irakijczyków, którzy ponieśli największą ofiarę związaną z procesem demokratyzacji państwa irackiego. Obalenie dyktatury Saddama Husajna, wytworzyło swoistą próżnię władzy, która ujawniła panujące w Iraku głębokie podziały społeczne oraz konflikty etniczno-religijne. Doprowadziły one do wybuchu brutalnej i długiej wojny, o skomplikowanej strukturze i trudnej do przewidzenia dynamice. Biorące w niej udział strony reprezentowały skrajnie różne motywy oraz cele, a także stosowały odmienne strategie oraz metody walki. Z perspektywy Stanów Zjednoczonych, konflikt iracki stanowił najtrudniejszą kampanię militarną od czasów wojny wietnamskiej. W trakcie działań zbrojnych w Iraku, tysiące żołnierzy amerykańskich straciło życie lub zostało rannych. Wojna generowała również ogromne koszty finansowe, związane z prowadzeniem operacji wojskowej oraz odbudową państwa irackiego.

Zrozumienie dynamiki toczącego się obecnie w Iraku konfliktu wymaga przypomnienia jego źródeł. Wkroczenie wojsk inwazyjnych do Iraku i obalenie rządów partii Baas wywołało stan chaosu i bezprawia, który dominował podczas pierwszych miesięcy działań okupacyjnych. Z czasem sytuacja w Iraku przybrała postać konfliktu zbrojnego z udziałem sił koalicji, nowoutworzonego rządu irackiego oraz pozarządowych organizacji zbrojnych wywodzących się z poszczególnych grup wyznaniowych i etnicznych w Iraku. Szczególnie problematyczne okazało się zbrojne powstanie, stanowiących mniejszość w Iraku, arabskich Sunnitów. Przez lata tworzyli oni społeczny fundament dyktatury partii Baas oraz stanowili najbardziej uprzywilejowaną grupę etniczno-religijną w okresie rządów Saddama Husajna. Zmiany, jakie niosła ze sobą amerykańska interwencja zbrojna, budziły wśród nich silny niepokój. Arabscy Sunnici obawiali się politycznej i ekonomicznej marginalizacji w państwie zdominowanym przez szyicką większość, wśród której pojawiały się tendencje rewanżystowskie. Rządy okupacyjne, w tym niektóre decyzje przez władze reprezentujące siły koalicji, umocniły wśród arabskich Sunnitów poczucie upokorzenia, które szybko zaowocowało zbrojnym oporem.

Struktura i charakter ruchu powstańczego ulegały stopniowej ewolucji. Pierwotnie był on zdominowany przez środowiska wywodzące się z rozwiązanych struktur ancien regime'u. Ich celem było zakończenie obcej okupacji oraz przeciwdziałanie procesom 
politycznym szkodzącym ich zdaniem interesom całej wspólnoty etniczno-religijnej. W przyjętej przez ugrupowania nacjonalistyczne taktyce walki, dominowały formy przemocy zaliczane do metod tzw. wojny partyzanckiej (miny pułapki, ostrzały konwojów wojskowych, niszczenie infrastruktury itp.). Z czasem siła, która zdominowała front sunnickiej rebelii w Iraku, stały się ugrupowania salafickie, skupiające ekstremistów dążących do realizacji idei państwa islamskiego. Dokonywane przez nich akty przemocy przybierały przeważnie formę ataków terrorystycznych, które wymierzone były najczęściej w ludność cywilną. Atakowane były również meczety oraz inne miejsca kultu religijnego Szyitów. Czyny te prowokowały działania odwetowe ze strony szyickich milicji, powiązanych ze środowiskami kleryckimi oraz niektórymi partiami politycznymi. W latach 2006-2007 na sile przybrała w Iraku przemoc międzywyznaniowa, która doprowadziła to państwo na skraj wojny domowej, grożącej jego rozpadem. Główny ciężar działań stabilizacyjnych ponosiły siły koalicji, które nie były jednak w stanie sprostać wyzwaniom związanym z konfliktem tego typu. Wysiłki na rzecz odbudowy irackich sił bezpieczeństwa nie przynosiły pożądanych efektów. Wojsko i policja nie dysponowały odpowiednio liczebną oraz dobrze przeszkoloną kadrą. Formacje te były ponadto spenetrowane przez szyickie milicje, przez co same w sobie stanowiły źródło problemu.

Brak wyraźnych postępów wpływał na wzrost niezadowolenia społeczeństwa amerykańskiego, którego spora część kwestionowała zasadność dalszego zaangażowania w Iraku i ponoszenia olbrzymich kosztów z tym związanych. Społeczny mandat dla prowadzenia działań wojennych w tym państwie ulegał wyczerpaniu. Dotychczasowa strategia okazała się być nieskuteczna i nieefektywna. Irak ogarnęła fala przemocy, która podkopywała wszelkie wysiłki na rzecz stabilizacji sytuacji w tym kraju. Wszechobecna przemoc hamowała proces demokratyzacji oraz odbudowy gospodarczej kraju, co wpływało na wzrost niezadowolenia irackiego społeczeństwa. Irak znajdował się w głębokim kryzysie, zaś siły koalicji nie dysponowały spójną i konsekwentnie wdrażaną strategią, zdolną odmienić bieg toczonej wojny.

$\mathrm{Na}$ początku 2007 r. podjęto próbę gruntownej reformy formuły prowadzonych w Iraku działań stabilizacyjnych. Najbardziej kontrowersyjnym elementem nowej koncepcji strategicznej, był plan wysłania do Iraku około pięciu dodatkowych dywizji (ponad 20 tys. żołnierzy) w celu wsparcia działań prowadzonych w Bagdadzie oraz prowincjach zdominowanych przez ludność sunnicką. Kwestia ta szybko stała się centralnym punktem publicznej debaty nad nową strategią. Plany administracji opatrzone zostały więc roboczym określeniem Surge (pol. napływ), który nie oddawał jednak w pełni ich istoty. Nowa koncepcja zakładała bowiem zaangażowanie szerokiego wachlarza środków i rozwiązań, które złożyły się na ostateczny rezultat w postaci wygaszenia poziomu przemocy. Głównym architektem oraz wykonawcą planu był gen. David Petreaus, twórca nowej doktryny działań przeciwpowstańczych (COIN, ang. Counter-Insurgency) sił zbrojnych Stanów Zjednoczonych.

Celem niniejszego artykułu jest wyjaśnienie najważniejszych przyczyn destabilizacji sytuacji w Iraku po 2011 r. oraz wskazanie politycznych uwarunkowań tego procesu. Za przyjęciem takiej cezury przemawia fakt, iż w roku 2011 zakończona została amerykańska misja wojskowa w Iraku, co w istotny sposób wpłynęło na sytuację polityczną w tym państwie oraz całym regionie. Zgodnie z przyjętą hipotezą, czynnikami, 
które zadecydowały o destabilizacji Iraku były: 1) pochopnie podjęta decyzja o całkowitym wycofaniu wojsk amerykańskich, której towarzyszył ogólny spadek zaangażowania w kwestie irackie ze strony administracji Baracka Obamy; 2) próby powrotu do rządów autorytarnych podejmowane przez premiera Nuriego al-Malikiego, które hamowały proces pojednania narodowego (w szczególności w relacjach szyicko-sunnickich); 3) wybuch wojny domowej w Syrii, podczas której wykształciły się i urosły w siłę ugrupowania ekstremistyczne, tworzące tzw. Państwo Islamskie. Tak sformułowany problem badawczy skłonił do zastosowania metody krytycznej analizy źródeł, w tym najnowszych publikacji i analiz, także materiałów prasowych. Metodę tę uzupełniła analiza decyzyjna, polegająca na wyodrębnieniu dominujących ośrodków uczestniczących w procesach decyzyjnych oraz wskazaniu najważniejszych uwarunkowań, które wpłynęły na treść oraz konsekwencje podejmowanych decyzji.

\section{SURGE - NIEWYKORZYSTANA SZANSA}

Działania podejmowane w ramach nowej koncepcji strategicznej Surge przyniosły oczekiwany przełom w kwestii prowadzonej w Iraku misji stabilizacyjnej. Tzw. doktryna Petraeusa oparta została na założeniu, że kluczowym warunkiem poprawy sytuacji bezpieczeństwa w Iraku jest uzyskanie wsparcia ze strony ludności cywilnej, zamieszkującej obszary objęte działalnością powstańczą. Cel ten wymagał przyjęcia całkowicie nowego schematu działań operacyjno-taktycznych oraz przewartościowania najważniejszych celów strategicznych wojny. Priorytetem przestało być fizyczne zniszczenie struktur ugrupowań biorących udział w rebelii, $w$ toku siermiężnie prowadzonych operacji wojskowych, w rodzaju działań podejmowanych w ramach pierwszej i drugiej bitwy o Faludżę (kwiecień-listopad 2004 r.). Na pierwszy plan wysunięto konieczność zapewnienia ludności poczucia trwałego bezpieczeństwa i odseparowania jej od wpływów przeciwnika. Osiągnięcie tego celu miało pozbawić rebeliantów swobody działania na obszarze objętym działaniami zbrojnymi. Pozbawiając powstańców swobodnego dostępu do bazy społecznej, ograniczono im możliwości związane z konspiracją swojej struktury polityczno-wojskowej oraz pozbawiono wsparcia o charakterze logistycznym, wywiadowczym, a także finansowym. Zakładano, iż osłabiając w ten sposób ugrupowania rebelianckie, doprowadzi się do wygaszenia fali przemocy i bezprawia w Iraku. Dzięki temu wytworzy się polityczna przestrzeń dla rekonstrukcji gospodarczej kraju, wzmocnienia struktur rządu irackiego oraz odbudowy irackich sił bezpieczeństwa (Dahlman, 2011: 193-194).

Realizacja tego celu wymagała przyjęcia całkowicie nowego modelu prowadzenia działań zbrojnych oraz podjęcia wielu inicjatyw o charakterze politycznym. Nowa doktryna zakładała tworzenie wspólnych posterunków bezpieczeństwa (ang. JSS, Joint Security Stations) na obszarze największych miast zagrożonych aktywnością rebeliantów. Obiekty te dzielone były z iracką policją oraz wojskiem, dzięki czemu formacje te były w stanie zdobyć odpowiednie umiejętności oraz doświadczenie. Stała obecność sił bezpieczeństwa na obszarach wysoko zaludnionych miała budować poczucie bezpieczeństwa oraz ułatwić codzienny kontakt z obywatelami Iraku. Żołnierze amerykańscy wyszli z wysuniętych i odseparowanych od świata zewnętrznego baz, próbując 
nawiązać konstruktywne relacje z Irakijczykami. Działano według nowego schematu: wyczyść - utrzymaj - odbuduj (ang. clear-hold-build) (Kilcullen, 2009: 124-139). Zmieniono również zasady oraz metody stosowania siły przez wojska amerykańskie. Incydenty związane z eskalacją przemocy stanowiły źródło rozgoryczenia ze strony ludności cywilnej w Iraku. Wiele rajdów czy operacji wojskowych prowadzonych było bowiem w sposób skutkujący dużą ilością ofiar pobocznych. Nowa doktryna zakładała stosowanie siły w sposób wywarzony i adekwatny do sytuacji. Wiązało się to z zaprzestaniem stosowania ataków z powietrza oraz ostrzałów z użyciem ciężkiej amunicji. Żołnierze amerykańscy musieli wykazać się większą powściaggliwością w stosunku do cywili, których przestano traktować jako potencjalnych agresorów (FM 3-24, 2006: 25).

Najważniejszym elementem nowej koncepcji strategicznej były działania podejmowane w wymiarze politycznym. Dowództwo sił koalicji doskonale rozumiało przyczyny oraz dynamikę panującej w Iraku przemocy międzywyznaniowej. Jej zasadniczym źródłem były silne resentymenty charakteryzujące relacje pomiędzy poszczególnymi grupami wyznaniowymi. Wśród irackich Sunnitów dominowały uczucia doznanej niesprawiedliwości oraz upokorzenia, a także nieufność wobec, rządzącej państwem, szyickiej większości. Ataki terrorystyczne organizowane przez iracki odłam Al-Kaidy działały w tym wypadku niczym katalizator, który wyzwalał nagromadzone pokłady nienawiści oraz prowokował szyickie milicje do akcji odwetowych, które napędzały spiralę przemocy (Fontan, 2009: 145-146). Jej przerwanie wymagało podjęcia działań na rzecz pojednania narodowego oraz przełamania wzajemnej nieufności. Administracja amerykańska, chciała w tym celu wykorzystać narastające podziały w obozie powstańców sunnickich. Idea ta przedstawiona została przez prezydenta G. W. Busha w orędziu o stanie państwa z 23 stycznia 2007 r. Zakładała wsparcie środowisk sunnickich, którym nie odpowiadał sposób działania skrajnych ugrupowań salafickich (Angell, Gunaratna, 2012: 22-24; Kilcullen, 2009: 98-99). Cele ekstremistów stały w sprzeczności z dążeniami innych ugrupowań powstańczych. Lokalni liderzy plemienni czuli coraz większą presję ze strony dżihadystów, którzy siłą wymuszali pełne posłuszeństwo ze strony lokalnych społeczności. Jakiekolwiek oznaki braku lojalności były brutalnie karane. Wśród arabskich Sunnitów pojawiła się refleksja, skłaniająca do podjęcia dialogu z siłami koalicji oraz strukturami rządu irackiego. Zjawisko to, nazwane Sunnickim Przebudzeniem, postępowało od końca 2005 r. W ramach strategii Surge zintensyfikowano działania zmierzające do rehabilitacji części środowisk powstańczych oraz włączenia ich w struktury irackich sił bezpieczeństwa (Shimko, 2010: 195-196).

W praktyce ruch Przebudzenia Sunnickego objął swoim zasięgiem przede wszystkim prowincję Anbar oraz terytoria zaliczane do tzw. trójkąta sunnickiego. Lokalni liderzy plemienni organizowali zbrojne oddziały, które otrzymywały finansowe oraz logistyczne wsparcie ze strony amerykańskich sił zbrojnych. Ich głównym celem było zwalczanie wpływów ugrupowań salafickich, a w szczególności walka z zagranicznymi bojownikami Al-Kaidy ${ }^{1}$, napływającymi do Iraku przez nieszczelne granice pań-

1 Szerzej na temat ideologii salafickiego ruchu globalnego dżihadu zob. A. Wejkszner (2010), Ewolucja terroryzmu motywowanego ideologia religijnq na przykladzie salafickiego ruchu globalnego dżihadu, Poznań. 
stwa. Strukturą dowódczą która koordynowała działalność lokalnych oddziałów była Rada Przebudzenia Anbaru. Skupiała ona blisko 54 tys. bojowników, z których część stopniowo włączana miała być w struktury irackiej policji lub wojska (Galbraith, 2008: 17-19; Shimko, 2010: 195-196).

Amerykańsko-sunnicki sojusz przeciwko dżihadystom w Iraku budził duże niezadowolenie wśród członków rządu irackiego oraz szyickich partii politycznych. Premier Nuri al-Maliki wyrażał wątpliwości co do szczerości intencji oraz lojalności ugrupowań sunnickich. Poddawany był jednak ogromnej presji ze strony administracji amerykańskiej, co ograniczało możliwości politycznego manewru w tej kwestii (Chulov, 2010). Dochodził do tego problem działalności szyickich milicji, których część powiązana była z rządzącymi Irakiem partiami politycznymi lub działała za przyzwoleniem i pod ochroną irackiego rządu. Administracja amerykańska oczekiwała od N. al-Malikiego działań zmierzających do ograniczenia ich wpływów oraz swobody działania. Szyickie bojówki miały zaprzestać ataków odwetowych wymierzonych w społeczność sunnicką oraz podporządkować się zasadom państwa prawa (Kagan, 2009: 39-41). Słusznie zakładano, że jedynie zaprzestanie przemocy z obu stron doprowadzić może do wypracowania przestrzeni dla kontynuowania procesu pojednania narodowego, który w największym stopniu warunkował postęp w zakresie stabilizacji sytuacji bezpieczeństwa w Iraku.

Podjęte w ramach strategii Surge działania stopniowo przynosiły pożądane rezultaty. 10 września 2007 r. gen. D. Petraeaus zaprezentował przed Kongresem raport na temat postępów misji stabilizacyjnej. Przedstawione przez niego dane świadczyły o spadku poziomu przemocy oraz poprawie w zakresie zaprowadzania ładu i bezpieczeństwa na ulicach irackich miast. Liczba cywilnych ofiar wojny spadła o blisko $45 \%$ w skali ogólnokrajowej oraz o 75\% w samym tylko Bagdadzie. Gen. D. Petraeus dodał również, że ilość ofiar przemocy międzywyznaniowej spadła o około 55\%. Najbardziej zauważalna poprawa sytuacji bezpieczeństwa wystapiła w prowincji Anbar (Report, 2007). W raporcie Departamentu Obrony z czerwca 2008 r. zaznaczono, że choć sytuacja w Iraku poprawiła się, to nadal istnieje duże ryzyko wybuchu kolejnej fali przemocy. Najważniejszą konsekwencją działań podejmowanych w ramach strategii Surge było znaczące osłabienie skrajnych ugrupowan salafickich, reprezentowanych przede wszystkim przez iracką Al-Kaidę (Measuring, 2008: 20-32). Pozytywny trend świadczący o poprawie sytuacji bezpieczeństwa w Iraku utrzymał się w ciaggu kolejnych lat, aż do momentu oficjalnego zakończenia misji sił koalicji w Iraku w $2011 \mathrm{r}$.

Poprawa sytuacji bezpieczeństwa w Iraku związana była z osłabieniem wpływów sunnickich ugrupowań ekstremistycznych oraz chwilowym załagodzeniem waśni etniczno-religijnych. Taki stan nie gwarantował jednak trwałego pokoju, a jedynie stwarzał szereg możliwości na zintensyfikowanie procesu pojednania narodowego. Choć głównym motorem napędowym działań podejmowanych w ramach strategii Surge były Stany Zjednoczone, to w wypadku długofalowych reform ustrojowych inicjatywa leżała po stronie irackich sił politycznych, w szczególności szyickiej koalicji wspierającej rząd N. al-Malikiego. Kluczowe znaczenie miało w tym względzie wywiązanie się z obietnic i deklaracji składanych w czasie negocjacji poprzedzających referendum konstytucyjne. Sunnici oczekiwali reform systemu politycznego, które zapewniłyby ich społeczności godną reprezentację oraz wpływ na politykę państwa. Najtrudniej- 
szym tematem była tzw. federalizacja Iraku oraz związany z nią podział zysków ze sprzedaży surowców naturalnych. Sunnici obawiali się bowiem politycznej i ekonomicznej marginalizacji. Nie chcieli znaleźć się pod presją dwóch silnych podmiotów (szyickiego i kurdyjskiego regionu autonomicznego), które zagarną większość bogactwa narodowego dla siebie. Pamiętać przy tym należy, że społeczność ta, przez długi czas, cieszyła się określonymi przywilejami jako główny beneficjent dawnego reżimu politycznego. Trudno więc było im zaakceptować scenariusz, w którym zostaliby zdegradowani do roli politycznego klienta (The Iraq Study, 2006: 18-19). Dochodził do tego problem reformy tzw. prawa debaasyfikacyjnego, które przez Sunnitów uznawane było za zbyt restrykcyjne i wymierzone w interesy tej społeczności (Hamoudi, 2014: 107-115).

Skomplikowane relacje sunnicko-szyickie stanowiły zasadnicze źródło napięć, które napędzały toczący się w Iraku konflikt zbrojny oraz utrudniały stabilizację sytuacji w tym państwie. Rozwiązanie tego problemu wymagało podjęcia szeregu trudnych reform politycznych oraz rozpoczęcia dialogu na rzecz pojednania narodowego. Celem tych działań powinno być zjednoczenie wszystkich grup etniczno-religijnych wokół idei państwowej, opartej na wspólnych celach i wartościach. Konsekwentnie wdrażana strategia osłabiania ugrupowań salafickich przyniosła pożądane efekty, stwarzając polityczną przestrzeń dla tego typu inicjatyw. Ich powodzenie zależało jednak od dobrej woli oraz determinacji ze strony irackich elit politycznych. Ich postawa była jednak trudna do przewidzenia, biorąc pod uwagę słabnącą presję ze strony Stanów Zjednoczonych, których nowe władze przygotowywały się do wycofania wojsk z Iraku pod koniec $2011 \mathrm{r}$.

Dla administracji Baracka Obamy, szybkie zakończenie misji wojskowej w Iraku stanowiło jedno z najważniejszych obietnic, złożonych podczas kampanii wyborczej w 2008 r. Nowy prezydent traktował wojnę iracką jako kłopotliwy spadek po poprzedniej administracji. Dążył do jak najszybszego zamknięcia tego rozdziału, co pozwoliłoby mu skupić pozostałe siły i środki na innych, jego zdaniem ważniejszych, zadaniach w ramach polityki bezpieczeństwa, m.in. na misji afgańskiej, która znajdowała się ówcześnie w impasie. Zdaniem Christophera Hilla, doświadczonego amerykańskiego dyplomaty oraz ambasadora Stanów Zjednoczonych w Iraku w latach 2009-2010, kwestia iracka nie wpisywała się w ogólną koncepcję polityki zagranicznej nowej administracji. Nierozwiązane problemy tego państwa, mogące z czasem doprowadzić jego do ponownej destabilizacji, zostały zignorowane lub zdjęte $\mathrm{z}$ agendy zadań priorytetowych (Hill, 2014).

W przemówieniu wygłoszonym 27 lutego 2009 r. prezydent B. Obama zapowiedział, że przed końcem sierpnia 2010 r. z Iraku wycofane zostaną wszystkie jednostki liniowe. Pozostałe siły, liczące 35-50 tys. żołnierzy, funkcjonować miały w charakterze misji szkoleniowej w ramach operacji New Dawn. Wojska amerykańskie miały wspomagać rząd iracki w zakresie szkolenia oraz dowodzenia formacjami wojska i policji. Administracja wyznaczyła również datę ostatecznego zakończenia misji wojskowej w Iraku na koniec 2011 r. (Brennan, Ries et al., 2014: 65-95, 287-292) Taki termin wymuszała na administracji treść umowy o statusie wojsk amerykańskich w Iraku (SOFA, Status of Forces Agreement), podpisanej jeszcze w 2008 r. przez prezydenta G. W. Busha oraz premiera N. al-Malikiego. Umowa zakładała, że wszelkie amerykań- 
skie operacje bojowe na terytorium irackim zostaną zakończone do połowy 2009 r., zaś całość sił koalicji zostanie wycofana do końca 2011 r., co wiązało się również z zakończeniem misji szkoleniowej. Do tego czasu wojska amerykańskie oraz działający na rzecz rządu USA kontraktorzy, mogli korzystać z immunitetu względem irackiego wymiaru sprawiedliwości (Mason, 2009: 7-11). Administracja dostrzegała potrzebę pozostawienia w Iraku niewielkiego kontyngentu wojskowego, którego siły ówczesny Sekretarz Obrony Robert Gates szacował na poziomie 5-10 tys. żołnierzy. Kontyngent ten miał odpowiadać za szkolenie i doradzanie irackim siłom bezpieczeństwa. W związku z wygaśnięciem umowy SOFA, plany te okazały się być niemożliwe do realizacji. Brak prawnych zabezpieczeń dla żołnierzy był nie do zaakceptowana dla dowództwa amerykańskich sił zbrojnych, zaś ewentualne przedłużenie umowy wymagało nowej tury trudnych negocjacji, do prowadzenia których żadna ze stron nie wykazywała woli politycznej (Gordon, 2012; Smalec, 2012: 53-55). Nadal obowiązywał amerykańsko-iracki traktat o współpracy strategicznej, ale nie zawierał on w swojej treści żadnych zapisów, które obligowałyby Stany Zjednoczone do podjęcia jakichkolwiek działań wojskowych w przyszłości (Cordesman, 2010: 1-5).

Konkludując, należy zaznaczyć, że działania podejmowane w ramach koncepcji strategicznej Surge, przyniosły wyczekiwany przełom w zakresie prowadzonej w Iraku misji wojskowej, zmierzającej do stabilizacji sytuacji w tym państwie. Zatrzymanie fali przemocy pozwoliło na rozpoczęcie procesu pojednania narodowego oraz umocnienie struktur państwa irackiego. Zapewnienie trwałego pokoju i bezpieczeństwa w Iraku uzależnione było jednak od postawy irackich przywódców politycznych, w szczególności partii reprezentujących interesy szyickiej większości. Stany Zjednoczone pozbyły się instrumentu nacisku w tym względzie, wycofując swoje siły wojskowe z regionu. W Iraku zabrakło gwaranta oraz głównego animatora, kluczowych dla powodzenia Surge przedsięwzięć. Dla administracji Baracka Obamy, wojna iracka stanowiła zamknięty rozdział amerykańskiej polityki zagranicznej. Uznano, że pozytywne efekty działań podejmowanych w ramach strategii Surge, oparte są na trwałym i solidnym fundamencie.

\section{NURI AL-MALIKI - PRÓBA POWROTU DO RZĄDÓW AUTORYTARNYCH}

Dzięki intensyfikacji działań stabilizacyjnych w latach 2007-2011, Irakijczycy zyskali cenny czas, potrzebny na realizację koniecznych reform politycznych. Miały one służyć przede wszystkim zainicjowaniu procesu pojednania narodowego oraz wzmocnieniu siły i autorytetu państwa irackiego. Kluczową rolę przy realizacji tego zadania odegrać miał ówczesny premier Nuri al-Maliki. Wywodzący się z partii Dawa polityk wyznania szyickiego rządził Irakiem od 2006 r. W 2010 r., w wyniku wielomiesięcznych negocjacji koalicyjnych oraz kontrowersyjnej decyzji Sądy Najwyższego, N. al-Maliki po raz kolejny zasiadł na fotelu premiera (The Iraq War, 2013: 256-257). Musiał przygotować, rządzone przez siebie państwo, na problemy i zagrożenia związane z faktem wycofywania się z Iraku obcych sił zbrojnych, które do tej pory ponosiły zasadniczy ciężar walki z ekstremistami. 
N. al-Maliki budził jednak w Iraku duże kontrowersje. Posądzano go o brak woli prowadzenia dialogu z opozycją, wrogi stosunek do społeczności arabskich Sunnitów oraz dążenie do sprawowania rządów autorytarnych. Przebieg jego drugiej kadencji na stanowisku premiera zdawał się potwierdzać stawiane zarzuty. Pierwszym wyraźnym sygnałem, świadczącym o zaostrzaniu polityki rządu N. al-Malikiego, było wydanie nakazu aresztowania wiceprezydenta Tarika al-Haszimiego, jednego z czołowych polityków reprezentujących interesy społeczności sunnickiej, którego premier publicznie oskarżył o wspieranie działalności terrorystycznej. Wydarzenie to miało miejsce zaledwie cztery dni po oficjalnym zakończeniu amerykańskiej obecności wojskowej w Ira$\mathrm{ku}$. W reakcji na działania premiera, sunniccy parlamentarzyści reprezentujący blok Irakija zagrozili oddaniem mandatów oraz wycofaniem z rządu swoich przedstawicieli. Domagali się również większego wpływu na resorty siłowe, które ich zdaniem zostały całkowicie zdominowane przez szyickich popleczników premiera N. al-Malikiego, i wykorzystywane były do zwalczania partii opozycyjnych (Brylew, 2014: 39; Cordesman, Khazai, 2012: 39-42).

N. al-Maliki kontynuował twardy kurs wobec opozycji. W marcu 2012 r. zmusił do odejścia z rządu kolejnego Sunnitę, ministra finansów Rafiego al-Issawiego, którego oskarżył o defraudację publicznych pieniędzy. Dymisji towarzyszyły aresztowania prominentnych polityków sunnickich, reprezentujących partie opozycyjne (Cordesman, Khazai, 2014: 101-103). N. al-Maliki przyjął również specyficzną metodę obsadzania najważniejszych resortów swoimi najbardziej zaufanymi współpracownikami. Omijał w tym względzie wymóg uzyskania zgody parlamentu, wykorzystując lukę w irackiej konstytucji, która pozwalała na mianowanie osób „pełniących obowiązki” ministra. W praktyce osobom tym przysługiwał ten sam zestaw uprawnień i prerogatyw, co ministrom zatwierdzonym przez organ ustawodawczy. Naginając obowiązujące prawo, N. al-Maliki uniezależniał się od parlamentu, co pozwalało mu na umocnienie i konsolidację swojej władzy (Brylew, 2014: 40).

Szczególnie krytykowany był sposób, w jaki iracki premier kierował strukturami siłowymi. Organizacje pozarządowe wyrażały głośnie zaniepokojenie w kwestii nieprzestrzegania podstawowych standardów związanych z ochroną praw człowieka i obywatela. Amnesty International oskarżało rząd N. al-Malikiego o dokonywanie pozasądowych egzekucji oraz porwań osób podejrzewanych o szeroko pojmowaną działalność antypaństwową. Członkowie sił bezpieczeństwa mieli dopuszczać się brutalnych tortur na więźniach, w tym gwałtów, podtopień, elektrowstrząsów oraz amputacji kończyn (Amnesty, 2013: 129-131). Szerokie uprawnienia w tym względzie dawała specjalna ustawa antyterrorystyczna, w szczególności artykuł 4, którego treść pozwalała na powszechne i nieskrępowane stosowanie kary śmierci. W okresie rządów N. al-Malikiego ustawa ta stanowiła zasadniczy instrument opresji (Brylew, 2014: 38).

N. al-Maliki dążył do pełnego podporządkowania sobie najważniejszych formacji sił bezpieczeństwa poprzez fragmentaryzację całej struktury łańcucha dowodzenia. Stworzył regionalne centra dowódcze, które obsadził zaufanymi oficerami. Pozbywał się przy tym doświadczonych i niezależnych dowódców, którzy wiedzę i umiejętności nabywali podczas operacji prowadzonych wspólnie z siłami koalicji. Szczególnie ważną dla premiera N. al-Malikiego formacją była Brygada Bagdadzka, kontrolująca sytuację w najważniejszych strategicznie częściach stolicy oraz na obszarach do niej 
przyległych. Spośród dowódców wszystkich czternastu dywizji irackich, jedenastu było Szyitami, jeden był Kurdem, zaś dwóch stanowiło zaufanych współpracowników premiera. Warto przy tym zaznaczyć, że najważniejszymi resortami siłowymi N. al-Maliki kierował osobiście, dążąc do pełnej koncentracji władzy w tym względzie (Sullivan, 2013: 10-19).

W czasie drugiej kadencji swoich rządów, iracki premier skupił się przede wszystkim na walce $\mathrm{z}$ opozycją oraz umacnianiu posiadanej władzy. Zlekceważył przy tym potrzebę przeprowadzenia gruntownych reform politycznych i gospodarczych, których oczekiwało irackie społeczeństwo. Gospodarka państwa oparta była wyłącznie na eksporcie ropy naftowej, zaś budżet państwa nie uwzględniał inwestycji o charakterze prorozwojowym, które mogłyby się przełożyć na ożywienie, w innych niż przemysł wydobywczy, gałęziach gospodarki oraz doprowadzić do przyrostu miejsc pracy. Szczególnie niezadowolenie wykazywali w tym względzie arabscy Sunnici, którzy odczuwali polityczną i ekonomiczną dyskryminację ze strony irackiego rządu. N. al-Maliki budował swoją bazę polityczną w oparciu o szyicką większość, która stała się dzięki temu głównym beneficjentem rozdzielanych przez rząd środków budżetowych (Qarawee, 2014). Społeczność sunnicka czuła coraz większe wykluczenie, także z powodu izolacji oraz prześladowań ugrupowań politycznych, reprezentujących jej interesy. Dotyczyło to w szczególności ponadwyznaniowego bloku Irakija, który w 2010 r. wygrał, z niewielką przewaga, wybory parlamentarne. Partia uzyskała szerokie poparciu wśród irackich Sunnitów, przekonanych, że jedynym sposobem na poprawę ich losu jest aktywny udział w procesie politycznym. Sukces wyborczy nie przełożył się jednak na udział w realnej władzy politycznej. Rząd zdominowany był przez koalicję szyicką, która wspierała premiera N. al-Malikiego, postrzegając go za głównego gwaranta zachowania szyickiej dominacji nad państwem (Brylew, 2014: 36).

Głównymi sprzymierzeńcami premiera były środowiska związane z Muktadą as-Sadrem oraz Najwyższa Rada Islamska w Iraku, której przewodzi ajatollah Said Ammar al-Hakim. Ugrupowania te reprezentują jednocześnie interesy sąsiedniego Iranu, który zyskał w N. al-Malikim oddanego sojusznika. Szyickie milicje mogły również liczyć na większą pobłażliwość ze strony rządu centralnego, zyskując swobodę działania oraz ochronę ze strony irackich sił bezpieczeństwa (Cordesman, Khazai, 2014: 151-157). Ugrupowania kurdyjskie, początkowo wspierające drugi rząd N. al-Malikiego, szybko weszły w konflikt z premierem. Źródłem napięć były nieuregulowane kwestie związane z eksploatacją, znajdujących się na terytorium regionu autonomicznego, złóż ropy naftowej. Spór rozgorzał przy okazji negocjacji dotyczących eksportu surowca do Turcji, który władze regionalne postanowiły prowadzić bez udziału przedstawicieli centralnego rządu irackiego. Na tym tle doszło nawet do zbrojnych incydentów z udziałem irackiego wojska oraz paramilitarnych oddziałów kurdyjskich Peszmergów (Cordesman, Khazai, 2014: 340-344).

Na przełomie 2012 i 2013 r. przez Irak przeszła fala protestów antyrządowych, obejmująca prowincje zamieszkane przez arabskich Sunnitów. Największe demonstracje miały miejsce w Faludży, Mosulu, Ramadi, Kirkuku i Bagdadzie. Większość z nich została stłumiona przez siły bezpieczeństwa. Protestujący domagali się ustąpienia premiera N. al-Malikiego oraz przeprowadzenia reform politycznych i gospodarczych. Pokojowe protesty, przeradzały się z czasem $\mathrm{w}$ regularne walki z udziałem irackiego 
wojska, policji oraz pozarządowych bojówek i milicji. Najbardziej gwałtowne starcia miały miejsce w Hawidży, leżącej na zachód od Kirkuku. W związku ze wzrostem napięcia w kraju, premier N. al-Maliki podjął kontrowersyjną decyzję o odroczeniu w czasie daty głosowania w ramach wyborów lokalnych w prowincjach dotkniętych zamieszkami. Spotkała się ona z jeszcze większym gniewem ze strony irackich Sunnitów, i w konsekwencji zaostrzyła konflikt (Make, 2013: 15-33).

W państwie rosła liczba aktów przemocy, które generowały coraz większą ilość ofiar śmiertelnych. Według przedstawicieli misji ONZ w Iraku, kwiecień 2013 r. był pod tym względem najbardziej tragicznym miesiącem, licząc od czerwca 2008 r. Zginęło blisko 712 osób, w tym 117 członków sił bezpieczeństwa (UN, 2013). Państwo irackie pogrążało się w coraz większym kryzysie wewnętrznym, którego główną osią był konflikt sunnicko-szyicki. Rządy N. al-Malikiego nie przyniosły oczekiwanych reform, które stanowić mogłyby podstawę dla procesu pojednania narodowego. Autorytarny styl rządzenia doprowadził do zaostrzenia relacji pomiędzy poszczególnymi grupami etnicznymi i wyznaniowymi. W 2013 r. do Iraku wróciła przemoc, która utrudniała podjęcie jakiegokolwiek dialogu. Taka sytuacja sprzyjała ugrupowaniom ekstremistycznym, które zyskały szansę na odbudowę utraconych wpływów.

\section{PAŃSTWO ISLAMSKIE - DROGA DO ROZPADU}

Nuri al-Maliki nie zdołał ukrócić korupcji, zasypać podziałów społecznych ani nawiązać konstruktywnego dialogu ze środowiskami politycznymi reprezentującymi interesy arabskich Sunnitów. Represyjność jego rządu zwiększyła się gdy Bliski Wschód ogarniać zaczęły protesty społeczne oraz konflikty zbrojne w ramach tzw. Arabskiej wiosny. Szczególnie problematyczna dla stabilności Iraku okazała się być wojna domowa w sąsiedniej Syrii. Powstanie wymierzone w dyktaturę prezydenta Baszara al-Assada przerodziło się w niezwykle brutalny konflikt, którego konsekwencje ponosić muszą również inne państwa regionu. Kulisy powstania Państwa Islamskiego w Iraku i Lewancie nie są do końca jasne. Zakłada się, że w ramach sił walczących z wojskami rządowymi w Syrii, wyłonił się radykalny odłam fundamentalistów islamskich, który na początku 2014 r. sprzymierzył się ze strukturami ekstremistów sunnickich, działających na terytorium Iraku. Powstała w wyniku fuzji organizacja nosić miała nazwę Islamskiego Państwa w Iraku i Lewancie, znanego szerzej pod anglojęzycznym skrótem ISIS (ang. Islamic State of Iraq and the Sham). Działalność tego ugrupowania skupiona była początkowo na obszarach pogranicza iracko-syryjskiego. ISIS w szybkim tempie przejmowało kontrolę nad kolejnymi miastami irackimi, posuwając się w głąb północnych prowincji kraju. Jego działalność destabilizowała państwo irackie, stanowiąc jednocześnie zagrożenie dla jego suwerenności oraz integralności terytorialnej (Plebani, 2014: 10-14).

Siły bezpieczeństwa w Iraku były bezsilne wobec rosnących wpływów ISIS. Ugrupowanie to posiadało bardzo radykalny program polityczny, przewidujący utworzenie na obszarze Syrii, Libanu oraz Iraku sunnickiego kalifatu, rządzonego zgodnie z najbardziej radykalną interpretacją zasad prawa szariatu. ISIS stanowiło ponadto dobrze zorganizowaną oraz dowodzoną strukturę, posiadającą odpowiednie siły i środki by 
zrealizować postawione przed sobą cele. Organizacja ta posiada bogate źródła finansowania, zaś jej bojownicy dysponują odpowiednim uzbrojeniem oraz doświadczeniem w walce (Blanchard, Humud, Nikitin 2014: 5-10).

29 czerwca 2014 r. ISIS ogłosiło powstanie na obszarach przez siebie kontrolowanych kalifatu pod nazwą Państwo Islamskie, ze stolicą w syryjskim mieście ar-Rakka. Na jego czele stanął samozwańczy kalif Abu Bakr al-Bagdadi. Kierowana przez niego struktura podjęła ofensywę zbrojną na północy Iraku, zajmując prowincję Anbar, Niniwa i Salahaddin, w tym miasta Faludża, Ramadi, Mosul i Tikrit. Na podbitym obszarze rebelianci wprowadzają rządy, w ramach których dokonują masowych egzekucji, wymuszając pełne posłuszeństwo ze strony lokalnej ludności. Dopuszczają się ponadto czystek na tle etnicznym i religijnym. Pod koniec czerwca 2014 r. siły Państwa Islamskiego stwarzały już bezpośrednie zagrożenie dla Bagdadu. W działania na rzecz rozwiązania kryzysu zaangażowały się przede wszystkim Stany Zjednoczone oraz Iran (Withnall, 2014). Przegrana irackiego rządu centralnego w starciu z siłami ekstremistów z Państwa Islamskiego może doprowadzić do rozpadu Iraku. W konsekwencji, na obszarze Bliskiego Wschodu, powstać może państwo kierowane przez sunnickich fundamentalistów, które służyć będzie jako baza dla działań terrorystycznych wymierzonych w państwa zachodnie.

W celu przeciwdziałania temu zagrożeniu Stany Zjednoczone przystąiły do formowania koalicji państw skłonnych do wzięcia czynnego udziału w działaniach zbrojnych wymierzonych w siły Państwa Islamskiego. Aktywność ta ogranicza się jednak wyłącznie do operacji prowadzonych z powietrza, których skuteczność jest często podważana (Malas, Nissenbaum, Abi-Habib, 2014). Ofensywa lądowa prowadzona jest wyłącznie przez irackie siły bezpieczeństwa oraz paramilitarne oddziały kurdyjskich Peszmergów (Chulov, 2014). Istotny wkład w działania wymierzone w Państwo Islamskie wnoszą szyickie milicje, wspierane przez irańskich doradców wojskowych. Szczególną rolę w tym względzie odgrywa gen. Kasem Sulejmani, dowódca oddziałów specjalnych al-Kuds, stanowiących integralną część irańskiej Gwardii Strażników Rewolucji (Pleasance, 2014). Wzrost siły szyickich milicji stanowić powinien powód do niepokoju. Ich działalność nie ogranicza się bowiem jedynie do walki z Państwem Islamskim. Członkowie milicji dopuszczają się zbrodni na ludności cywilnej, prowadząc operacje noszące znamiona czystek etnicznych (Kirkpatrick, 2014).

O sile Państwa Islamskiego decyduje szereg różnych czynników. Po pierwsze, jest to twór bazujący na niezwykle radykalnej ideologii, która od lat inspiruje oraz przyciąga rzesze muzułmanów z Bliskiego Wschodu, Afryki, Azji czy Europy. Doniosła wizja budowy islamskiego kalifatu, jako podmiotu wolnego od wpływów Zachodu i opartego na skrajnie ortodoksyjnej interpretacji prawa szariatu, skłania ochotników z całego świata do wzięcia udziału w fanatycznej walce, która często kończy się dla nich męczeńską śmiercią. Fundamentaliści dążą również do przezwyciężenia dziedzictwa europejskiego kolonializmu, którego namacalnym symbolem są obowiązujące do dzisiaj granice państwowe, ustalone na mocy umowy Sykes-Picot, podpisanej w $1916 \mathrm{r}$. (por. Rabinovich 2014: 1-9). Idea połączenia wyznawców proroka pod egidą nowego państwa (kalifatu) przemawia do wyobraźni wielu muzułmanów. Czynnikiem mobilizującym do aktywnego udziału w toczącej się krucjacie są przede wszystkim rzeczywiste sukcesy tej organizacji, odnoszone w walce z siłami rządowymi Iraku i Syrii. 
Po drugie, pamiętać należy, że ISIS nie jest kolejnym wcieleniem organizacji terrorystycznej, ale próbą stworzenia rzeczywistego państwa, rozumianego jako polityczna jednostka terytorialna wyposażona we władzę centralną. Państwo Islamskie rozbudowuje swój aparat, czyniąc go zdolnym do kontrolowania zdobytego terytorium oraz zamieszkującej go ludności. Ustanawia prawa, sprawuje władzę sądowniczą oraz zapewnia dostęp do szeregu usług publicznych. Państwo Islamskie dysponuje ponadto środkami finansowymi, uzyskiwanymi z nielegalnej sprzedaży ropy naftowej, wydobywanej na kontrolowanych przez siebie obszarach. Budżet zasilany jest również wpływami z podatku nałożonego na ludność cywilną (zakat) oraz ze środków uzyskanych od sympatyków lub bogatych sponsorów (Plebani 2014: 14-20; Rasheed, 2014).

Po trzecie, Państwo Islamskie narodziło się w bardzo sprzyjających warunkach postępującej destabilizacji na obszarze całego Bliskiego Wschodu. Wojna domowa w Syrii oraz konflikt wewnętrzny w Iraku stworzyły żyzny grunt dla działalności islamskich organizacji ekstremistycznych. Słabość rządów państw tego regionu, uwidoczniona w trakcie wydarzeń określanych mianem Arabskiej wiosny, stanowi czynnik sprzyjający radykalnym ideologiom, oferującym alternatywę dla wartości właściwych ustrojom opartym na reżimie demokratycznym. Bazą społeczną dla działalności Państwa Islamskiego w Iraku jest przede wszystkim ludność sunnicka, zawiedziona przyniesioną przez Stany Zjednoczone demokracją oraz pełna nieufności wobec rządzących państwem Szyitów.

Powyższa analiza wskazuje, że Państwo Islamskie stanowi problem regionalny, którego rozwiązanie przekracza możliwości rządów pojedynczych państw. W przypadku Iraku stawką tego konfliktu jest zachowanie integralności terytorialnej. 30 kwietnia 2014 r. odbyły się w tym państwie wybory parlamentarne, których wyniki trudno uznać za reprezentatywne, ze względu na utrudnione warunki prowadzenia głosowania w prowincjach sunnickich. Pod wpływem międzynarodowej presji, ze stanowiska premiera ustapił Nuri al-Maliki. Zastapił go Haidar al-Abadi - Szyita uważany za polityka umiarkowanego i skłonnego do dialogu (Harding, 2014). Stoi przed nim szereg niezwykle trudnych zadań i problemów do rozwiązania. Najważniejszym wyzwaniem pozostaje zjednoczenie poszczególnych grup etnicznych i wyznaniowych w Iraku w walce z Państwem Islamskim. W obecnych warunkach, odzyskanie zaufania społeczności sunnickiej wydaje się być jednak zadaniem nierealnym. Ponadto, zamieszkujący Irak Kurdowie coraz śmielej deklarują chęć stworzenia samodzielnego państwa. 1 lipca 2014 r. prezydent kurdyjskiego regionu autonomicznego Masud Barzani zapowiedział rozpisanie referendum niepodległościowego na obszarach zamieszkanych przez irackich Kurdów. Ze względu na trwające walki z bojownikami Państwa Islamskiego, głosowanie zostało odłożone w czasie (Parkinson, Entous, 2014). Nie zmienia to jednak faktu, że państwo irackie ulega powolnemu rozpadowi, zaś proces ten będzie bardzo trudny do zatrzymania (por. Sasnal, 2014: 1-2).

Amerykańska inwazja na Irak, której konsekwencją było obalenie dyktatury Saddama Husajna, ujawniła głębokie podziały i konflikty panujące w narodzie irackim. Przybrały one postać brutalnego konfliktu zbrojnego, który toczył to państwo przez kolejne 
lata. Dzięki właściwie przemyślanej oraz konsekwentnie wdrażanej strategii, siłom koalicji udało się ustabilizować Irak, w stopniu pozwalającym na zakończenie misji wojskowej oraz wycofanie żołnierzy z terytorium tego państwa. Utrzymanie tego stanu wymagało od Irakijczyków podjęcia rzeczywistego dialogu na rzecz pojednania narodowego.

Rządy Nuriego al-Malikiego nie przyniosły oczekiwanych reform. Autorytarny styl sprawowania władzy doprowadził do zaostrzenia relacji pomiędzy poszczególnymi grupami wyznaniowymi i etnicznymi w Iraku. Na ulice irackich miast powracała przemoc, która pochłaniała kolejne ofiary, napędzając spiralę nienawiści. Ekstremistyczne ugrupowania sunnickie, odbudowywały utracone wpływy. Rząd prowadził politykę, która w coraz większym stopniu antagonizowała irackie społeczeństwo, nie wykazując przy tym woli do prowadzenia dialogu z opozycja. W efekcie wyczerpane zostały pozostałe pokłady wzajemnego zaufania. N. al-Maliki nie wykorzystał historycznej szansy odbudowy państwa irackiego, trwoniąc dorobek działań stabilizacyjnych prowadzonych w ramach strategii Surge.

Powstanie oraz ekspansja Państwa Islamskiego, stanowiło w dużej mierze konsekwencje trwającej w Syrii wojny domowej. Reprezentowane przez tą organizacje idee, trafiły w Iraku na bardzo podatny grunt. Rząd centralny okazał się przy tym zbyt słaby, aby skutecznie przeciwstawić się zbrojnej ofensywie fundamentalistów. Obecna sytuacja jest więc konsekwencją szeregu zaniedbań oraz błędów, popełnionych zarówno ze strony irackiej, jak ze strony Stanów Zjednoczonych, które zbyt pochopnie podjęły decyzje o wycofaniu swoich wojsk z regionu. Konsekwencją może być rozpad Iraku oraz powstanie państwa wyznaniowego, kierowanego przez sunnickich fundamentalistów i dążącego do destabilizacji całego regionu bliskowschodniego.

\section{Bibliografia}

Amnesty International Report 2013. The State of The World's Human Rights, Amnesty International http://files.amnesty.org/air13/AmnestyInternational_AnnualReport2013_complete_en.pdf (12.12.2014).

April bloodiest month in Iraq since 2008: U.N, „Reuters” 02.05.2013.

Blanchard Ch., Humud C., Nikitin M. (2014), Armed conflict in Syria. Overview and U.S. response, Congressional Research Service Report, Washington.

Brennan R., Ries C. et al. (2013), Ending the U.S. war in Iraq: the final transition, operational maneuver, and disestablishment of United States Forces-Iraq, Santa Monica.

Brylew M. (2014), Nouri al-Maliki, a charismatic leader or a new dictator of Iraq?, w: Multi-vector politics in modern Asia, (eds.) J. Marszałek-Kawa, E. Kaja, Toruń.

Chulov M. (2010), Sons of Iraq turned the tide for the US. Now they pay the price, „The Guardian” 13.05.2010.

Chulov M. (2014), Islamic State has exposed peshmerga's military vulnerability, „The Guardian” 12.08.2014.

Cordesman A. (2010), Iraq and the United States: Creating a Strategic Partnership, Center for Strategic and International Studies, June 2010, Washington.

Cordesman A., Khazai S. (2012), Iraq After US Withdrawal: US Policy and the Iraqi Search for Security and Stability, Center for Strategic and International Studies, Washington. 
Cordesman A., Khazai S. (2014), Iraq in Crisis, Center for Strategic and International Studies, Washington.

Dahlman C. T. (2011), Breaking Iraq: Reconstruction as War, w: Reconstructing Conflict: Integrating War and Post-War Geographies, (eds.) S. Kirsch, C. Flint, Surrey.

FM 3-24. Counterinsurgency (2006), Headquarters Department of Army Washington, http://bl-libg-doghill.ads.iu.edu/gpd-web/coin-fm3-24.pdf (12.03.2014).

Fontan V. (2009), Voices from post-Saddam Iraq. Living with terrorism, insurgency, and new forms of tyranny, London.

Galbraith P. (2008), Unintended Consequences. How War in Iraq Strengthened America's Enemies, New York.

Gordon M. (2012), In U.S. Exit From Iraq, Failed Efforts and Challenges, „The New York Times”, 22.09.2012.

Hamoudi H. A. (2014), Negotiating in Civil Conflict: Constitutional Construction and Imperfect Bargaining in Iraq, Chicago-London.

Harding L. (2014), Haider al-Abadi: from exile in Britain to Iraq's next prime minister, „The Guardian" 11.08.2014.

Hill. Ch. (2014), How the Obama Administration Ignored Iraq. One ambassador's story of an exit strategy gone wrong, ,The Politico”, http://www.politico.com/magazine/story/2014/10/how-the-obama-administration-disowned-iraq-111565.html\#.VKQgo3uoM5x (12.11.2014).

Kagan K. (2009), The Surge: A Military History, New York.

Kilcullen D. (2009), The Accidental Guerrilla. Fighting Small Wars in the Midst of a Big One, New York.

Kirkpatrick D. (2014), Sunnis Fear Permanent Displacement From Iraqi Town, „New York Times”, 5.12.2014.

Make or Break: Iraq's Sunnis and the State (2013), Crisis Group Middle East Report, No. 144.

Malas N., Nissenbaum D., Abi-Habib M. (2014), U.S.-led Airstrikes Disrupt Islamic State, But Extremists Hold Territory, „The Wall Street Journal”, 5.10.2014.

Mason C. R. (2009), U.S.-Iraq Withdrawal/Status of Forces Agreement: Issues for Congressional Oversight, Congressional Research Service Report, Washington.

Measuring stability and security in Iraq (2008), Report to Congress in accordance with the Department of Defense Appropriations Act 2008 (Section 9010).

Parkinson J., Entous A. (2014), How Kurds Came to Play Key Role in U.S. Plans to Combat Islamic State, „The Wall Street Journal”, 8.09.2014.

Pleasance C. (2014), How Iraq's military is fighting back ISIS... under the guidance of Iran's powerful general, „Daily Mail”, 5.11.2014.

Plebani A. (2014), The unfolding legacy of Al-Qa'ida in Iraq: from al-Zarqawi to the new Islamic Qaliphate, w: New (and old) patterns of jihadism: Al-Qa'ida, the Islamic State and beyond, (eds.) A. Plebani, Milan.

Qarawee H. (2014), Iraq's budget problems go beyond Erbil-Baghdad crisis, „Al-Monitor”, 28.02.2014.

Rabinovich I. (2014), The End of Sykes-Picot? Reflections on the Prospects of the Arab State System, Middle East Memo, No. 32, Washington.

Rasheed A. (2014), Oil smuggling finances Islamic State's new caliphate, „Reuters”, 23.07.2014.

Report to Congress on the situation in Iraq. General David H. Petraeus. Commander, Multi-National Force-Iraq (2007), http://www.defense.gov/pubs/pdfs/Petraeus-Testimony20070910.pdf (20.04.2014). 
Sasnal P. (2014), Scenariusze rozwoju kryzysu w Iraku, „Biuletyn PISM” nr 81 (1193), $\mathrm{http}: / / w w w . p i s m . p l /$ files/?id_plik=17647, 29.01.2015.

Shimko K. L. (2010), The Iraq Wars and America's Military Revolution, New York.

Smalec Ł. (2012), Polityka bezpieczeństwa Stanów Zjednoczonych wobec Iraku 2001-2011, w: Stracona dekada? Polityka bezpieczeństwa Stanów Zjednoczonych wobec ,, globalnych obszarów niestabilności” (Iraku, Iranu, KRL-D oraz Afganistanu) w latach 2001-2011, (red.) Ł. Smalec, Warszawa.

Sullivan M. (2013), Malikis Authoritarian Regime, Middle East Security Report 10, Institute for The Study of War, Washington.

The Iraq Study Group Report: The Way Forward - A New Approach (2006), (eds.) J. Baker, L. Hamilton, et al., http://media.usip.org/reports/iraq_study_group_report.pdf (11.02.2014).

The Iraq war encyclopedia (2013), (ed.) T. Mockaitis, Santa Barbara.

Wejkszner A. (2010), Ewolucja terroryzmu motywowanego ideologia religijnq na przykładzie salafickiego ruchu globalnego dżihadu, Poznań.

Withnall A. (2014), Iraq crisis: Isis declares its territories a new Islamic state with 'restoration of caliphate' in Middle East, „The Independent”, 30.06.2014.

\title{
STRESZCZENIE
}

Celem artykułu jest ukazanie dynamiki wydarzeń, które doprowadziły do destabilizacji sytuacji w Iraku po wycofaniu się z tego państwa wojsk amerykańskich. Wyjaśnione zostały czynniki, które doprowadziły do wzrostu napięć w relacjach międzywyznaniowych oraz uwarunkowania wzrostu znaczenia ugrupowań ekstremistycznych. Kluczowym punktem analizy jest wyjaśnienie przyczyn sukcesu tzw. Państwa Islamskiego, stanowiącego zagrożenie o charakterze ponadregionalnym. Działalność tej organizacji doprowadzić może do rozpadu Iraku oraz destabilizacji całego Bliskiego Wschodu.

\section{FROM SURGE TO ISLAMIC STATE. CAUSES AND DETERMINANTS OF DESTABILIZATION IN IRAQ AFTER 2011}

\begin{abstract}
The aim of this paper is to examine main causes and determinants that have contributed to the destabilization of Iraq after the withdrawal of American forces in 2011. The focus will be on the factors that caused the increase in sectarian violence, especially in respect to Shia-Sunni relations. The paper also explains main chain of events that created favorable conditions for the emergence of the Islamic State. An organization which pose a threat to the entire region and can lead to disintegration of Iraq.
\end{abstract}


